\title{
Research regarding the managers' behavior towards employees within sports organizations
}

\section{Paul F. DRAGOȘ ${ }^{1}$, Dana I. CRISTEA ${ }^{2}$}

\section{Abstract}

Starting from the definitions found in the literature, according to which the management is strictly related to the manner in which managers behave and act in their relationship with the employees and to the manner in which their behavior can influence the subordinates' motivation, the conducted research wishes to establish the presence of these elements in the daily activities and their role increasing performance within sports organizations.

Therefore, based on the analysis of the data gathered through the survey, a series of action plans can be outlined for the improvement of the work relationships at the level of managers and employees.

Key words: motivation, sport, action, collaboration, management

\section{Rezumat}

Pornind de la definițiile apărute în literatura de specialitate conform cărora managementul este strâns legat de modul în care managerii se comportă și acționează în relația cu angajații dar și influența comportamentului acestora asupra motivației subordonaților, prin cercetarea întreprinsă se încearcă să se stabilească măsura în care toate aceste aspecte se regăsesc în activitatea practică în direcția creșterii performanțelor din cadrul organizațiile sportive.

Astfel, pe baza analizei datelor culese cu ajutorul chestionarului, se desprind o serie de direcții de acțiune în perspectiva optimizării relațiilor de muncă la nivelul managerilor și angajaților.

Cuvinte cheie: motivație, sport, acțiune, colaborare, management

\footnotetext{
${ }^{1}$ Assistant professor PhD, Faculty of Geography, Tourism and Sport, University of Oradea, email: dpaul@uoradea.ro

${ }^{2}$ Lecturer PhD, Faculty of Geography, Tourism and Sport, University of Oradea, email: danacristea07@yahoo.com
} 


\section{Introduction}

Sports, through its organization and manifestation forms, through its built specific infrastructure, has become an inseparable part of society in general, the differences being of quantitative and qualitative nature and whose value is generated by the involvement degree of each actor as part of the society (of the whole) [1].

The management of sport phenomenon, which in the last decade has encountered a spectacular expansion in the world, both quantitatively and qualitatively, required the discovery, use and adaptation of new methods of guiding and modernizing structures of sports organizations [2]. According to the slogan "the right man in the right place", the efficiency of an organization is related mostly to the people that belong to it. The chain starts with the manager that needs to prove real leadership qualities, which means he needs to make the most of the employees' innate talents in order to improve their efficiency in the activities that they develop [3][4]. This is also emphasized by several definitions of management that were given over time.

Thus, according to Kreitner [5], the management is "an activity developed with and through other people in order to achieve the organization's objectives, by efficiently using the limited resources of a continuously changing environment". Samuel Certo [6] considers the management as a process of attaining the organization's objectives by working with and through people and by using other resources of that organization. Moreover, Stephen Robbins [7] states that the management is a process of efficient accomplishment of the activity with and through people.

Another definition given to management in this direction belongs to the American researcher Mary Parker Follet, quoted by Dănăiață, Bibu and Predișcan [8], who sees the management as "the art of activating the accomplishment of certain things with the help of people" or, in other words, "management means being able to determine other people to perform a specific task"

Donnelly, Ivancevich and Gibson [9] define management as a "process developed by one or several persons meant to coordinate the activities of other persons in order to obtain results that could not be obtained through individual action".

As suggested by the above mentioned definitions, the attitude of managers in general and the attitude of managers in the sports organizations in particular, their actions at the work place and their behavior influence the manner in which employees carry out their tasks, their efficiency and especially their motivation at work.
Motivation [10] is the manner in which a persistent effort is directed in order to achieve a certain goal. Beyond all motivational theories, which can be more or less applicable, it is more interesting to observe the organizations' and managers' openmindedness in regard to the acknowledgement and promotion of employees and in mapping out individual development plans for their employees.

The leaders who succeed in helping their employees accomplish their own goals never encounter problems related to their motivation. The accomplishment of one's own goal always keeps that person motivated. The manager only needs to find the connection between one's personal goal and the needs of the organization [11].

\section{Hypothesis and purpose}

The managers' attitude towards their subordinates constitutes a particularly important motivating factor in the process of achieving the individual, group or institutional objectives of a sports organization.

In this respect, it is relevant to carry out an analysis on the manner in which the actions related to the management of human resources within the concerned sports organizations motivate the personnel and support it in order to increase performances.

\section{Materials and methods}

The choice of research methods and techniques has been made according to the studied issue, with the established objectives and hypotheses, endeavor which has allowed us to get to know the studied phenomena in relation with up to date theories, practices and realities. In consequence, the following methods and techniques have been chosen:

- Study of specialty literature

- Questionnaire

After establishing the research approach strategy, the author decided to carry out the study on a number of 60 managers and 140 employees of differed sports organizations. Because of some of the potential respondents' reserves and because of the mistakes that occurred in filling out the questionnaire, we have managed to gather a number of 51 correctly filled in questionnaires from managers and 127 from employees.

The sampling was mixed (random and directed) because of the following reasons:

sports organizations of various sizes and statuses were taken into consideration;

from each type, the investigated subjects were selected first of all according to their availability to respond to the questionnaire. 
The sample was subjected to analysis through the following:

- geographical area (in the case of managers 23\% from the total of subjects are from Oradea, $21 \%$ from Cluj Napoca, about 20\% from Timișoara and Bistriţa and $8 \%$ from Arad. In the case of employees, from Oradea were enrolled in the research study $26 \%$, from Bistriţa $21 \%$, from Timişoara 20\%, from Cluj Napoca $18 \%$ and from Arad 15\%);

- the size of the organization $(12 \%$ of respondents among both managers and employees are part of small sports organizations. $27 \%$ of managers and $20 \%$ of the employees belong to medium size sports clubs, $61 \%$ of managers and $68 \%$ of the employees are part of larger sports organizations);

- the position within the organization $229 \%$ of managers are directors, $23 \%$ are vice presidents, $12 \%$ are presidents; $12 \%$ deputy directors; also $12 \%$ are counselors; $6 \%$ financial officers and 6\% administrators. From the employees group: teacher-coach $38 \%$, coaches $24 \%$, organizers of competitions $8 \%$ and $5 \%$ head of departments and reviewers. Also, a small percentage (4\%) are reviewers, secretaries and clerks. There is a category of $8 \%$ occupied by other staff (caretakers, drivers etc.);

- study level $(53 \%$ of the managers with a bachelor's degree, 29\% postgraduate diploma and $18 \%$ hold a PhD. The majority of employees (52\%) have a bachelor's degree, 23\% attended postgraduate and only $27 \%$ only graduated high school);

- the age of the subjects $47 \%$ of managers are between $46-55$ years old, $24 \%$ are between 36 45 years old, and the same $24 \%$ are between 56-65. Among employees, $31 \%$ are up to 35 years old, and between 46-55 years, $22 \%$ were between 36 and 45 years and the remaining $16 \%$ are over 56 years);

- gender (88\% from managers and 80\% from employees are men);

The data interpretation that followed the analysis of certain points revealed important aspects regarding the attitude of managers towards employees, like the importance that certain managers give to the human resources, the perception of managers on their subordinated employed personnel, their general opinion on the professional development of employees and on the work relationships.

\section{Results}

Figure 1 highlights the importance that managers give to the human resources, as they determine the level and the quality of results. $59 \%$ of them agreed with this idea, while $41 \%$ consider that the purpose/results are the most important.

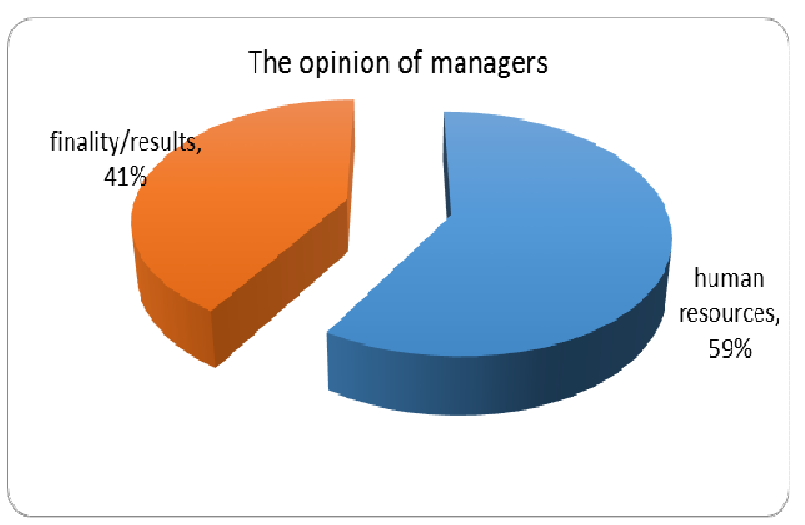

Figure 1. Which aspects deserve more attention?

The perception of managers on their subordinated employed personnel (Fig. 2) illustrates a positive point of view, that is to say that employees are considered specialists needed for an efficient activity (59\% of the respondents). The opinion expressed by managers can only highlight the respect that is shown towards employees, which is highly motivating for the activity developed in an organization.

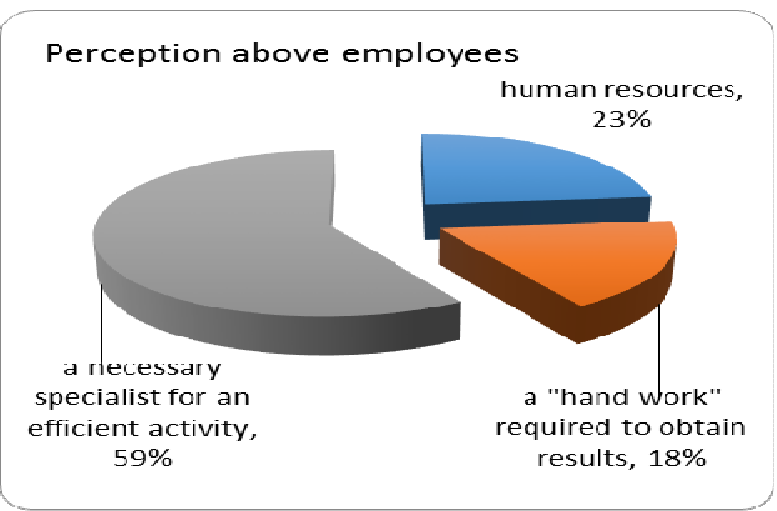

Figure 2. The opinion of managers

At the opposite pole we can observe that $18 \%$ of the respondents consider employees as simple "manpower" necessary for obtaining results, while $23 \%$ of the respondents see them as nothing more than "the organization's human resources".

The statistics are approximately the same from the point of view of the employees (Fig. 3). 


\section{Perception above employees}

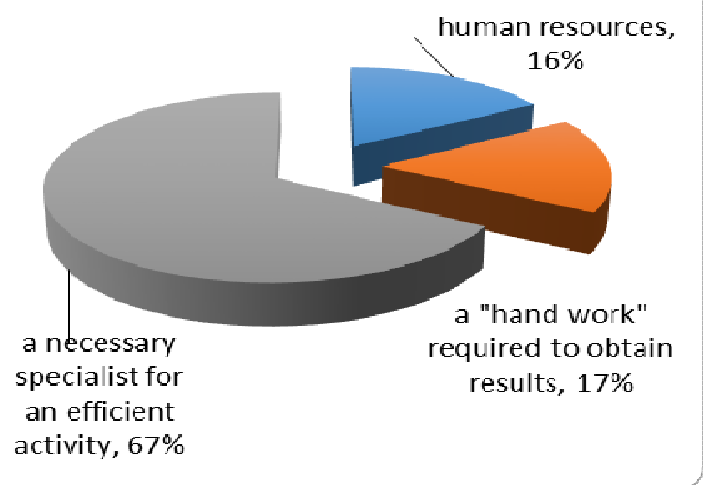

Figure 3. The opinion of employees

They consider, in proportion of $67 \%$, that they are treated as "specialists needed for an efficient activity", which gives them confidence, increases their personal acknowledgement and inevitably motivates them. Only $16 \%$ of them consider that they are seen as "the organization's human resources", while $17 \%$ as the necessary "manpower" for achieving the objectives.

In our case (Fig. 4), most of the managers' answers, $59 \%$, show that they consider the professional trainings for employees as a necessary investment for the organization, an aspect considered as positive at least from a theoretical point of view.

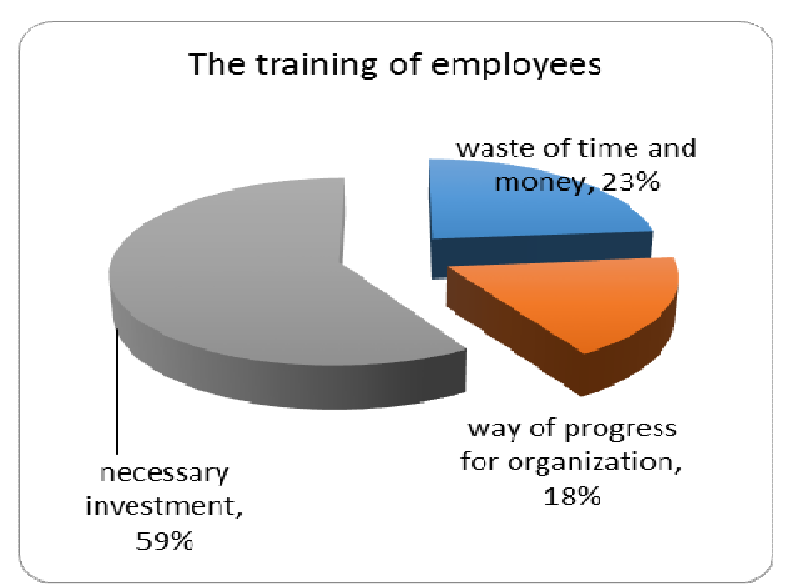

Figure 4. The opinion of managers

If we compare the answers received to this question with the answers given to the question about the mangers' perception on employees, we can observe a certain connection

The opinion of „employees”is represented below (Fig. 5).

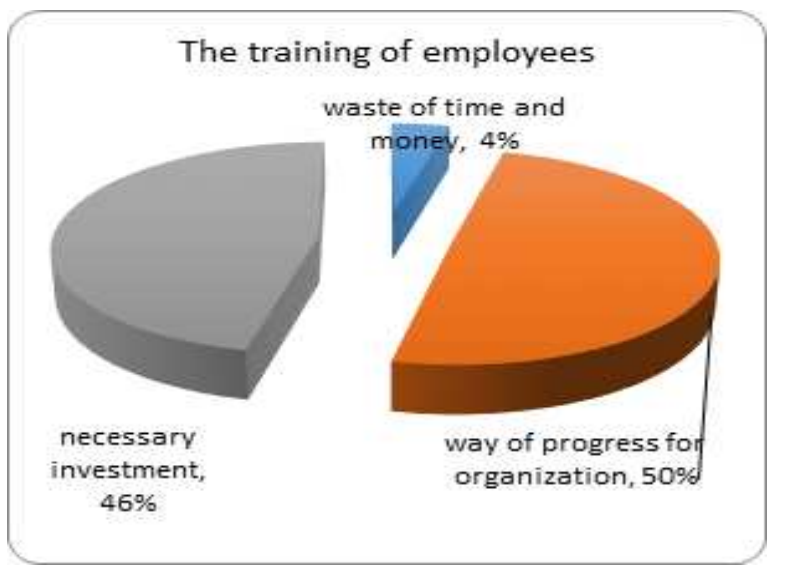

Figure 5. The opinion of the employees

More precisely, it is the same percentage of $59 \%$ of the answers that shows us that the employees are seen as "specialists needed for an efficient activity" and, in consequence, that their professional training represents a beneficial investment for the organization.

Moreover, $18 \%$ of the managers believe that the professional training of the employees represents a progress tool for the organization, while $23 \%$ of them see it as a waste of time and money. When compared to the educational background of each survey participant, the obtained results reveal the respondents' opinion in regards to the professional training of the employees. We can notice the opinion of the managers with higher education and of the employees between 46-55 years old who consider the professional training as an investment necessary for the organization. Furthermore, most of the employees with higher education consider this element as a means of progress for the organization.

The opposite pole is represented by the managers between 16-45 years old and a series of employees between 46-65 years old who consider the professional training as a waste of time and money. The same idea is shared by a part of the managers with postgraduate studies and of the employees with higher education.

From the point of view of the employees, the professional training is considered a means of progress (50\%) and an investment beneficial for the organization (46\%).

Only $4 \%$ of the respondents state that the professional training is a waste of time and money.

In what concerns their relationship with the employees, most of the managers tend to adopt the collaboration method ( $88 \%$ of the respondents). (Fig. 6). 


\section{Relation with employees}

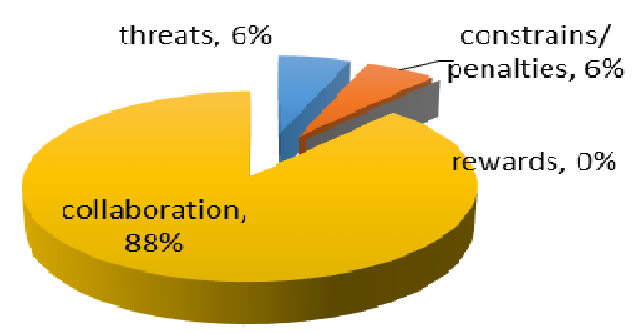

Figure 6. The opinion of the managers

On the other side we find the threats and the constraints/penalties that are used by only $6 \%$ of the questioned managers. The too often reward used in the relationship with the employees is not accepted by any of the survey participants.

The employees have a similar point of view as they see the collaboration as the most frequent method of interaction (87\%), the differences surfacing when it comes to the reward method that was chosen by $13 \%$ of the respondents. The threats and the constraints/penalties do not appear as being frequently used in the relationship between managers and subordinates. (Fig.7)

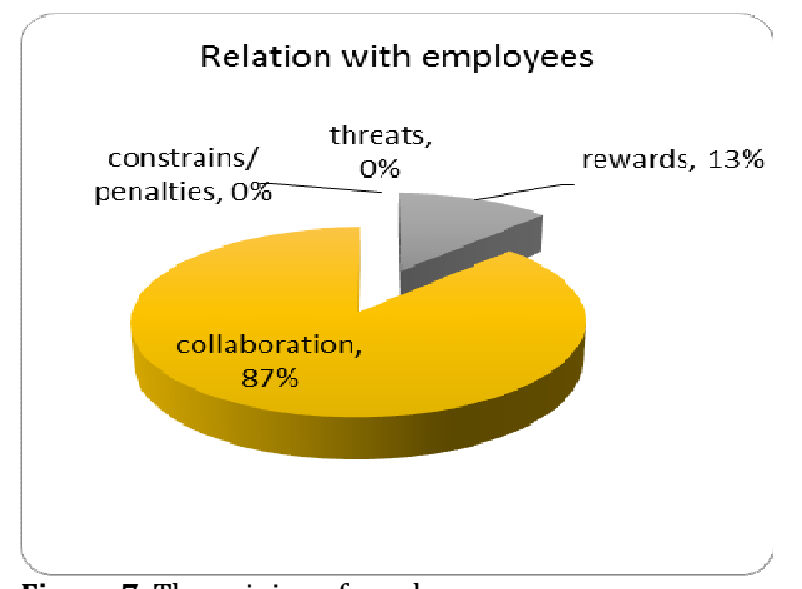

Figure 7. The opinion of employees

\section{Discussions}

The managers must understand the reasons for which individuals act in a certain manner and for which they have certain reactions in distressing situations or in situations in which they are meant to be influenced. A useful understanding method is to determine the actions that the managers should carry out in order to achieve the organizational objectives and the actions that they actually carry out [12] [13].
The professional training is meant to provide basic qualifications for a certain profession but also continuous improvement or new qualifications in order to meet the competitiveness of the labor market and in order to fight against the unemployment and the professional reconversion determined by the social-economic restructuring. [14].

By invoking the mobility of the workforce, managers prefer to recruit already specialized workers or to adapt the positions for the unqualified workers. According to specialists, Romania has a great setback because of the fact that managers, especially owners, refuse to invest in the professional training of their employees. They prefer, most of the times, to use unqualified personnel for a certain position.

\section{Conclusions}

The respect of managers towards the employed personnel, and implicitly the manner in which they approach certain situations that can appear in the sports organizations, plays an important role in what concerns the motivation at the workplace.

The attitude of managers in their relationship with the employees depends both on their professional experience and their education, personality or even family.

The professional training of the employees constitutes an important motivating element as it can improve the professional skills and it can provide chances for progress and promotions. It doesn't necessary mean that this method is applied, but the fact that the managers' opinion is positive in this regard creates premises for its frequent introduction in the daily activities.

In what concerns the relationship with the employees, we can state that the collaboration method can lead to remarkable results in sports organizations and the effect of this method can represent an engine for the development of healthy communication relations by helping to create trustbased connections which are important in the life of each organization.

\section{References}

1. Ilieș A, Dehoorne 0., Wendt J., Kozma G., (2014), For Geography and Sport, Sport Geography or Geography of Sport, GeoSport for Society, volume 1, no 1-2, pag. 7-18

2. Buhaș S.D., (2015), Sport Management - Science and Art, Analele Universităţii din Oradea, Facicula Educație Fizică şi Sport, Rev. nr. XXV /2015 pag. 85-89

3. Girginov V., (2008), Management of sports development, Butterworth-Heinemann, Elsevier, pag. 10.

4. Watt Dc, (2003), Sports management and administration, Taylor \& Francis e-Library, pag. 68-72.

5. Kreitner R. (2008), Principles of management, Cengage Learning, Hampshire, pag. 6. 
6. Certo S.C. (1988), Principles of modern management: functions and systems, Allyn \& Bacon; 4 Sub edition, Boston, pag. 10.

7. Robbins S.P. (2012), The truth about managing people (3rd Edition), FT Press, New Jersey, pag. 9.

8. Dănăiaţă I., Bibu N., Predișcan M. (2002), Managementbazele teoretice, Mirton, Timişoara, pag. 12.

9. Gibson J.L., Ivancevich J.M., Donnelly J.H. (2000), Organizations: behavior, structure, processes, Irwin/ McGraw-Hill, New York, pag. 9.

10. Johns G. (1998), Comportament organizaţional, Economică, Bucrești, pag. 150.

11. Hoye D.R., et. all (2009), Sport management: principles and applications, Elsevier Ltd., pag. 77.

12. Arnold H.J., Feldman, D.C., (1986), Organizational behavior, New York: McGraw-Hill Book Company, New York, pag. 215-220

13. Heckhausen J., Heckhausen H., (2008), Motivation and action: Introduction and overview, University Press, Cambridge, pag. 384-386

14. Lussier R.M., Kimball D.C. (2014), Applied sport management skills, Second edition, Human Kinetics, Published in USA, pag. 235. 